\title{
Dexamethasone can stimulate G1-S phase transition in human airway fibroblasts in
} asthma

\author{
B. Fouty*, T. Moss" ${ }^{\#}$, V. Solodushko* and M. Kraft
}

ABSTRACT: Corticosteroids are the first line of therapy for asthma. Whether they alter the progression of airway remodelling in asthma is, as yet, unknown.

To determine whether corticosteroids could alter the fibroblast cell cycle the current authors studied the effect of dexamethasone on cultured airway fibroblasts obtained from nine mild-tomoderate, steroid-naïve asthmatics (forced expiratory volume in one second $78 \pm 4 \%$ predicted), and seven normal controls. Fibroblasts were cultured from endobronchial biopsies obtained via bronchoscopy. Cells were exposed to dexamethasone $\left(10^{-9}-10^{-7} \mathrm{M}\right)$ and studied at $72 \mathrm{~h}$ to determine differences in progression through the cell cycle.

In asthmatic fibroblasts, dexamethasone, at concentrations of $10^{-8} \mathrm{M}$ and $10^{-7} \mathrm{M}$, nearly doubled the number of cells in the $S$ phase $(17.8 \pm 3.0 \%$ and $18.4 \pm 3.1 \%$, respectively) compared with untreated fibroblasts $(\mathbf{1 0 . 3} \pm \mathbf{1 . 4 \%})$. There was no significant effect in normal control fibroblasts. Dexamethasone induced hyperphosphorylation of the tumour suppressor, retinoblastoma (RB) in asthmatic fibroblasts; fibroblasts from normal controls had significantly less hyperphosphorylation of RB. No difference in protein expression of the CCAAT/enhancer binding protein $\alpha$ between the two groups was detected.

This study suggests that dexamethasone can stimulate G1-S phase cell cycle transition in human airway fibroblasts obtained from asthmatics. Whether this leads to enhanced airway remodelling in some individuals remains to be determined.

KEYWORDS: Asthma, cell cycle, dexamethasone, fibroblast

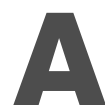
irway remodelling in asthma is a pathological process that can eventually lead to fixed airway obstruction. The mechanisms leading to airway remodelling include smooth muscle cell proliferation (both hypertrophy and hyperplasia), goblet cell hyperplasia, and collagen deposition [1]. Airway fibroblasts (and myofibroblasts) are important in mediating many of the changes seen in advanced asthma [2]. Located adjacent to the airway epithelium, fibroblasts produce collagen and also secrete cytokines that may attract inflammatory cells to the airway that can perpetuate the inflammatory and fibrotic process in asthma [3, 4].

Inhaled corticosteroids have been the cornerstone of asthma therapy since the late 1990s [5] and while the anti-inflammatory effects of steroids are well documented, their effects on controlling remodelling are less clear. A report by RoTH et al. [6] supports the concept that steroids control inflammation and proliferation in asthma through separate pathways. The group demonstrate that while the loss of the CCAAT/enhancer binding protein $\alpha(\mathrm{C} / \mathrm{EBP} \alpha)$ in bronchial smooth muscle had no effect on glucocorticoid-mediated inhibition of interleukin-6 release, it completely prevented steroids from inhibiting cell proliferation. The selective loss of $C / E B P \alpha$ from the bronchial smooth muscle of asthmatics (peripheral lymphocytes still expressing $C / E B P \alpha$ ) was suggested as being partly responsible for both the enhanced airway smooth muscle proliferation in asthmatics and the failure of steroids to abrogate it. Whether airway fibroblasts from asthmatics exhibit a similarly enhanced proliferative potential or resistance to glucocorticoids is not certain.

The current authors previously examined the effect of corticosteroids on DNA synthesis in fibroblasts obtained from asthmatics [7]. Dexamethasone increased DNA synthesis in cultured airway fibroblasts from asthmatics, an effect that was most prominent in cells from mild asthmatics. Whether this response is beneficial or

\section{AFFILIATIONS}

*Division of Pulmonary and Critical Care Medicine and the Center for Lung Biology, University of South Alabama, Mobile, AL, and

\# Dept of Medicine, National Jewish Medical and Research Center, and the University of Colorado Health Sciences Center, Denver, CO, and -Dept of Medicine, and the Duke Asthma, Allergy and Airway Center, Duke University Medical Center, Durham, NC, USA.

CORRESPONDENCE

B. Fouty

Center for Lung Biology

MSB 3340

University of South Alabama School of Medicine

Mobile, AL

36688

USA

Fax: 12514607452

E-mail: bfouty@jaguar1.usouthal.edu

Received:

July 052005

Accepted after revision:

February 212006

\section{SUPPORT STATEMENT}

This work was supported by the following grants from the National Institutes of Health/National Heart Lung and Blood Institute: R01 HL070273 (B. Fouty) and HL64619 (M. Kraft).

European Respiratory Journal Print ISSN 0903-1936 Online ISSN 1399-3003 
detrimental is not clear; however, it does stand in contrast to the effects of corticosteroids on fibroblasts in other organ systems, where proliferation was either decreased or unchanged [8-10]. To further investigate the effects of corticosteroids on airway fibroblast function in asthma, the present authors also examined the effect of dexamethasone on cell cycle proteins and cell cycle progression in airway fibroblasts cultured from asthmatic individuals. The authors demonstrate that at baseline, untreated fibroblasts from asthmatics have an increased number of cells in the $S$ phase, relative to those from normal controls. In addition, dexamethasone was found to induce hyperphosphorylation of the tumour suppressor retinoblastoma (RB) in fibroblasts from asthmatics and stimulate them to progress through the cell cycle, whereas it had no stimulatory effect on fibroblasts from normal controls.

\section{MATERIALS AND METHODS Subjects}

Nine asthmatic subjects with moderate asthma (forced expiratory volume in one second (FEV1) $78 \pm 4 \%$ predicted), as defined by the National Asthma Education and Prevention Program, and seven normal controls (FEV1 101 $\pm 5 \%$ pred) were recruited from the general Denver (CO, USA) community. All asthmatic subjects met diagnostic criteria for asthma [11], exhibiting a methacholine provocative concentration causing a $20 \%$ fall in FEV1 (PC20) $<8 \mathrm{mg} \cdot \mathrm{mL}^{-1}$ and were only maintained on inhaled $\beta_{2}$-agonists, using on average $1-2$ puffs $\cdot$ day $^{-1}$. All subjects were atopic by clinical history and skin testing to common Colorado aeroallergens (defined as $>1$ positive skin test). The healthy group had no history of asthma and no bronchial hyperresponsiveness (methacholine PC20 $>25 \mathrm{mg} \cdot \mathrm{mL}^{-1}$ ). Exclusion criteria included: 1) use of inhaled or oral corticosteroids, leukotriene modifiers, theophylline, cromolyn and/or nedocromil within the previous 6 weeks; 2 ) an upper respiratory tract infection within the previous 6 weeks; 3) immunotherapy within the previous 3 months; 4) cigarette use of $>5$ pack-yrs, and any cigarette use within the past year; and 5) significant nonasthma pulmonary disease or other medical illnesses. Informed consent was obtained from all patients for this institutional, review board, approved protocol.

\section{Bronchoscopy}

Subjects underwent bronchoscopy with endobronchial biopsy as previously described [12]. The site of biopsy was randomised to either the right or left lower lobe and five-to-six endobronchial biopsy specimens were taken from the tertiary carinae of the right or left lower lobes, under direct visualisation. Prior to bronchoscopy, spirometry was performed before and after the administration of $0.18 \mathrm{mg}$ of albuterol from a metered dose inhaler and $0.4 \mathrm{mg}$ atropine via i.v. Lidocaine $(4 \%)$ was used to anaesthetise the upper airway, and lidocaine $(1 \%)$ was applied to the laryngeal area, trachea and orifice of the right lower or left lower lobe bronchi via the bronchoscope. Supplemental oxygen was administered throughout the procedure, in addition the heart rate and oxygen saturation were also monitored. The subjects' vital signs were monitored in the laboratory after the procedure and subjects were discharged once FEV1 was $90 \%$ of the pre-bronchoscopy and post-bronchodilator value.

\section{Materials}

Dulbecco's minimum essential medium (DMEM), Ipegal, propridium iodide, and RNAse were all obtained from Sigma (St. Louis, MO, USA), Trypsin-EDTA, L-glutamine from Gibco (Grand Island, NY, USA), foetal bovine serum (FBS) from Gemini (Woodland, CA, USA), and polyvinylidene diflouride (PVDF) membrane and ECL-plus from Amersham (Buckinghamshire, UK). Antibodies: $\alpha-\mathrm{p} 21^{\mathrm{Cip} 1}$ (c-19) and $\alpha-\mathrm{C} /$ $\operatorname{EBP} \alpha(\sigma \chi-61)$ were obtained from Santa Cruz Biotechnology (Santa Cruz, CA, USA), $\alpha$-p2 $7^{\mathrm{Kip} 1}$ and $\alpha$-retinoblastoma (both mouse monoclonal) from Pharmigen (San Diego, CA, USA), and $\alpha$ - $\beta$-actin (mouse monoclonal) from Sigma. Secondary horseradish peroxidise (HRP)-conjugated antibodies: donkey $\alpha$-mouse, donkey $\alpha$-rabbit from Jackson Labs (West Grove, NJ, USA).

\section{Fibroblast culture}

Fibroblasts were cultured from endobronchial biopsy tissue as previously described [12]. Briefly, biopsy specimens were rinsed and cut into several small pieces ( $\sim$ five-six per biopsy) and placed into wells (two pieces $\cdot$ well $^{-1}$ ) of a 24-well tissue culture plate, containing DMEM, supplemented with $10 \%$ FBS, streptomycin $\left(100 \mu \mathrm{g} \cdot \mathrm{mL}^{-1}\right)$, penicillin $\left(10,000 \mathrm{U} \cdot \mathrm{mL}^{-1}\right)$, and gentamicin $\left(100 \mu \mathrm{g} \cdot \mathrm{mL}^{-1}\right)$. The tissue pieces were incubated at $37^{\circ} \mathrm{C}$ with $5 \%$ carbon dioxide and cultured until cell growth was established, $>50 \%$ confluency $(\sim 8-20$ days), the media was changed every $2-3$ days. Upon reaching $>50 \%$ confluency, the tissue pieces were removed and the cells were trypsinised, counted, tested for viability and stained for identification. Additionally, cells were seeded in T25 flasks for subsequent cell passages (Becton Dickinson, Franklin Lakes, NJ, USA). All cells were stained with monoclonal mouse antihuman antibodies against fibroblast antigen (Ab-1; Calbiochem, San Diego, CA, USA), vimentin (DAKO, Carpinteria, CA, USA) and smooth muscle $\alpha$-actin (DAKO). Of the cells, $>99 \%$ stained positive for $\mathrm{Ab}-1$ and vimentin and negative for smooth muscle $\alpha$-actin, confirming them as fibroblasts. Only cells from the first through the third passages were used for experiments. Cells were trypsinised and plated into either 6-well plates (for cell cycle analysis) or T-25 flasks (for protein). Cells were plated in DMEM with $0.5 \%$ FBS. Either dexamethasone, at increasing concentrations $\left(10^{-9}-10^{-7} \mathrm{M}\right)$, or vehicle control was added to the cells at the time they were plated, the cells were studied at $72 \mathrm{~h}$.

\section{Flow cytometry}

Cell cycle was determined by flow cytometry in propidium iodide stained cells as previously described [13]. After $72 \mathrm{~h}$ in dexamethasone or control, cells were digested with trypsinEDTA from the culture plates and the trypsin inactivated by addition of DMEM with $10 \%$ FBS. Cells were collected by low centrifugation, washed with PBS, recollected by centrifugation, stained with Krishan's solution (propridium iodide, sodium citrate. $2 \mathrm{H}_{2} \mathrm{O}$; Ipegal, Sigma), boiled RNAse and incubated overnight at $4^{\circ} \mathrm{C}$. The cells were then analysed in the University of Colorado Health Science Centre's (Denver, CO, USA) Flow cytometry core using a Beckman Epics-XL flow cytometer. Histograms of DNA content were analysed using Modfit LT software to determine fractions of the population in each phase of the cell cycle (G0/G1, S, G2/M). 


\section{Western blot analysis}

At the same time that cells were harvested for flow cytometry (see above) cells in $100 \mathrm{~mm}^{3}$ dishes were washed with cold PBS, lysed in radioimmunoassay buffer (PBS, 1\% ipegal, $0.5 \%$ sodium deoxycholate, $0.1 \%$ sodium dodecyl sulphate (SDS), phenylmethylsulfonyl fluoride $\left(10 \mathrm{mg} \cdot \mathrm{mL}^{-1}\right)$, aprotinin $\left(30 \mu \mathrm{L} \cdot \mathrm{mL}^{-1}\right)$, and sodium orthovanadate $\left.[1 \mathrm{mM}]\right)$, pelleted at $14,000 \times g$ and the protein concentration of the supernatant determined by Bradford assay. Equal amounts of protein were separated by SDS-polyacrylamide gel electrophoresis under reducing conditions ( $1 \% \beta$-mercaptoethanol) using either 14 or $6 \%$ gels. The proteins were then transferred to PVDF membrane in $20 \%$ methanol. Membrane was blocked in $1 \%$ nonfat milk and $0.1 \%$ Tween-20, probed with appropriate antibodies (see Materials section), detected with appropriate secondary antibodies conjugated to HRP at 1:10,000 dilution and detected using ECL-plus (Amersham). Protein expression was quantified using National Institutes of Health image 1.63 and expressed as arbitrary density units relative to baseline (cells incubated without dexamethasone) as previously described [14].

\section{Statistical analysis}

The percentage of cells in S phase with dexamethasone was compared with the negative control within the asthmatic and control group, respectively, via a mixed effects model that evaluated repeated measures with contrasts between each condition and the respective negative control. Contrasts were performed at each concentration of dexamethasone to evaluate concentration differences between treated and untreated fibroblasts within each group and treated fibroblasts between each group. A p-value $<0.05$ was considered significant. The data are presented as the mean \pm SEM.

\section{RESULTS}

\section{Subject characteristics}

Subject characteristics are shown in table 1.

\section{Dexamethasone increases the number of asthmatic airway fibroblasts in $\mathbf{S}$ phase}

Early passaged human airway fibroblasts from either asthmatic or normal individuals were cultured in the presence of

\begin{tabular}{lccc}
\hline TABLE 1 & $\begin{array}{c}\text { Subject characteristics } \\
\text { Normal } \\
\text { controls }\end{array}$ & Asthma & p-value \\
& & & \\
\hline Sex & 4 & 4 & \\
Male & 3 & 5 & \\
Female & $32.4 \pm 3.4$ & $32.2 \pm 3.7$ & 0.13 \\
Age yrs & None & $\beta_{2}$-agonists & \\
Medication & $4.5 \pm 0.2$ & $3.1 \pm 0.2$ & 0.001 \\
FEV $\mathbf{1}$ L & $101 \pm 4$ & $78 \pm 4 \%$ & 0.002 \\
FEV 1 \% & & & \\
$\quad$ predicted & & & \\
\hline
\end{tabular}

Data presented as $\mathrm{n}$ or mean $\pm \mathrm{SEM}$. FEV1: forced expiratory volume in one second. increasing doses of dexamethasone for $72 \mathrm{~h}$. Cells were then harvested, stained with propidium iodide, and analysed by flow cytometry. Figure 1 is a representative cell cycle profile of fibroblasts from a normal ( $a$ and b) and an asthmatic (c and d) individual. It demonstrates that following exposure to $10^{-7} \mathrm{M}$ dexamethasone the percentage of fibroblasts in $S$ phase from asthmatic subjects increased whereas there was little effect on normal fibroblasts. The aggregate cell cycle data for all experiments at various concentrations of dexamethasone is shown in figure 1 (e and f). Fibroblasts cultured from asthmatics had a significant increase $(\mathrm{p}<0.05)$ in cells in $S$ phase at both $10^{-8} \mathrm{M}(17.8 \pm 2.9 \%)$ and $10^{-7} \mathrm{M}(18.4 \pm 3.1 \%)$ concentrations of dexamethasone compared with untreated controls $(10.3 \pm 1.4 \%)$. This was associated with a significant decrease in the percentage of cells in G0/G1, but no change in the percentage of cells in G2/M phase. In contrast, fibroblasts from normal controls had no significant increase in cells in the S phase $(6.3 \pm 1.1 \%)$ when exposed to $10^{-8} \mathrm{M}(7.9 \pm 1.6 \%)$ or $10^{-7}$ M $(8.2 \pm 1.9 \%)$ dexamethasone. In addition, even at baseline (no dexamethasone), there were more asthmatic fibroblasts in the $S$ phase than fibroblasts from normal controls $(10.3 \pm 1.4$ versus $6.3 \pm 1.1 \%, \mathrm{p}<0.05)$.

Figure 2 demonstrates the variability in response to dexamethasone among individual subjects. While the baseline $\mathrm{S}$ phase population varied in the asthmatic cells there was a consistent increase in cell cycle progression, following exposure to dexamethasone, whereas there was very little effect in the normal controls.

\section{Dexamethasone induces hyperphosphorylation of retinoblastoma in airway fibroblasts from asthmatics}

Cell progression through the G1/S transition into $S$ phase requires that the tumour suppressor RB be hyperphosphorylated $[15,16]$. Hyperphosphorylation releases the inhibitory effect of RB on the transcription factor E2F which is important for the transactivation of genes required for DNA synthesis. The current study's data indicates that dexamethasone stimulated airway fibroblasts from asthmatics to progress through G0/G1 phase into S phase. Therefore, it should be possible to detect that dexamethasone induced the hyperphosphorylation of RB. The protein was harvested and RB hyperphosphorylation was assessed both in the asthmatic and normal cells. Figure 3 confirms that dexamethasone led to the hyperphosphorylation of RB in airway fibroblasts from asthmatics. While hyperphosphorylation of RB did occur in the cells of some normal controls it was significantly less than in asthmatic cells. This observation is consistent with the flow cytometry data presented above.

\section{Dexamethasone does not induce $p 21^{\text {Cip1 }}$ or $p 27^{\text {Kip } 1}$ expression}

Hyperphosphorylation (and inactivation) of RB occurs through the sequential action of two G1 protein complexes, cyclin Dcdk4 and cyclin E-cdk2 [15]. The kinase function of both these cyclin-cyclin dependent kinase (cdk) complexes can be blocked by the cdk inhibitors $\mathrm{p} 21^{\mathrm{Cip} 1}$ and $\mathrm{p} 27^{\mathrm{Kip} 1}$ [16]. When they bind to the cyclin-cdk complexes they prevent the hyperphosphorylation of RB which causes G1 arrest. The anti-proliferative effects of rapamycin [17] and 3-hydroxy 3-methylglutaryl coenzyme A reductase inhibitors (the statins) [18], are thought 

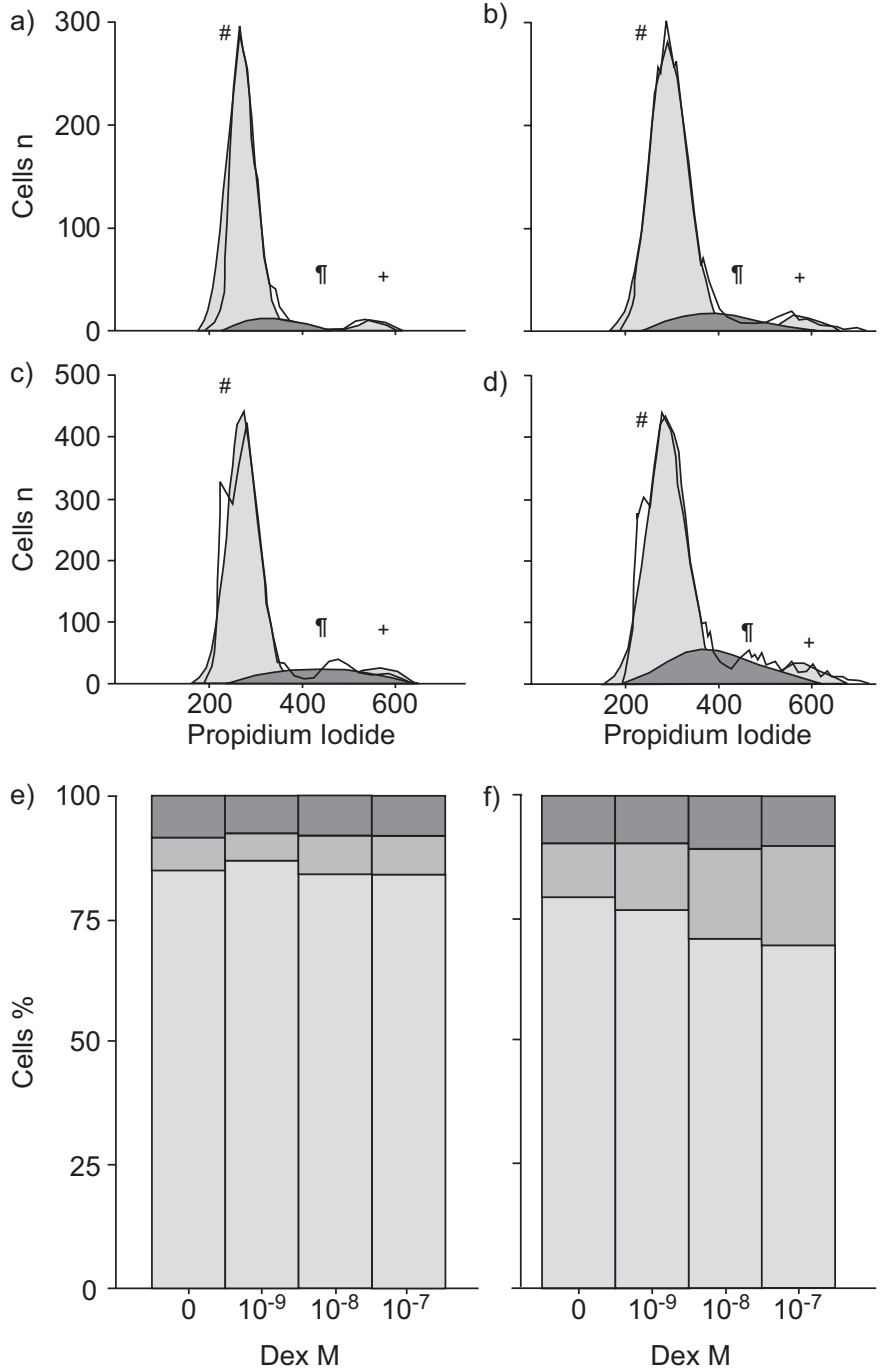

FIGURE 1. Dexamethasone (Dex) stimulates human airway fibroblasts from individuals with asthma into the $S$ phase. a-d) Representative cell cycle profiles of fibroblasts from normal ( $a$ and $b$ ) and asthmatic (c and d) subjects when exposed to Dex at $10^{-7}$ M. *: G1 phase; ": S phase; ${ }^{+}$: G2 phase. e and f) represent the aggregate cell cycle data of all the experiments performed in separate patients in normal control group $(n=7)$ and in the asthmatic group ( $n=9$; e and f, respectively). Dex at $10^{-8}$ and $10^{-7} \mathrm{M}$ significantly increased the number of asthmatic cells in the $\mathrm{S}$ phase ( $\square$ ) and decreased the number of asthmatic cells in Go/G1 phase ( $\square$, $p<0.05$ ), but had no effect on cells from normal controls. No significant change in cells in G2/M phase ( $\square$ ) was detected.

to work, at least in part, through the upregulation of $\mathrm{p} 21^{\mathrm{Cip} 1}$ or $\mathrm{p} 27^{\mathrm{Kip} 1}$. As a possible explanation for its proliferative effect on airway fibroblasts harvested from asthmatics, protein levels of $\mathrm{p} 21^{\mathrm{Cip} 1}$ and $\mathrm{p} 27^{\mathrm{Kip} 1}$ were observed to determine whether either was downregulated by dexamethasone. No downregulation of either $\mathrm{p} 21^{\mathrm{Cip} 1}$ or $\mathrm{p} 27^{\mathrm{Kip} 1}$ in airway fibroblasts was detected from asthmatics after $72 \mathrm{~h}$ of dexamethasone exposure. In addition no dexamethasone-induced increase in cyclin D1 (an early G1 protein important in cell cycle progression) was detected. As expected there was some variation between individuals, but as opposed to the consistent effect of dexamethasone
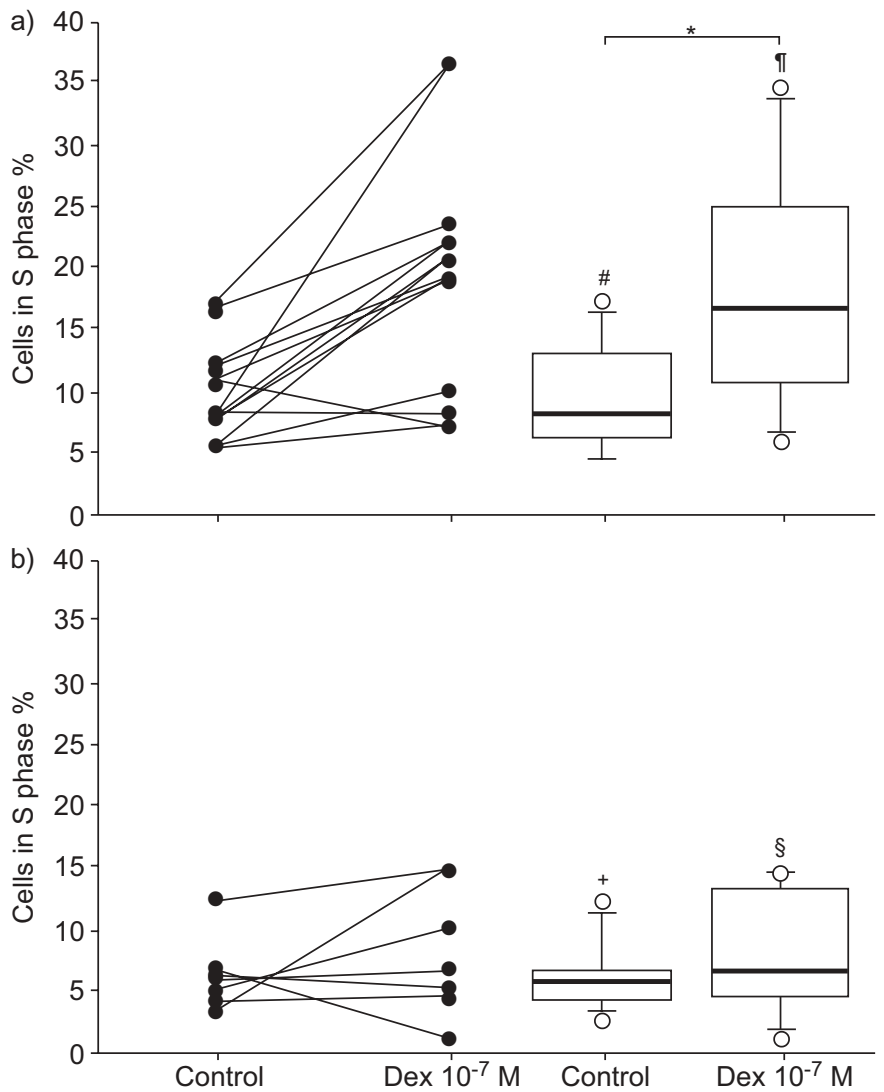

FIGURE 2. Effect of dexamethasone (Dex) on fibroblasts from a) individual asthmatics $(n=9)$ and $b)$ normal controls $(n=7)$. The figure demonstrates the varied responses among fibroblasts from each group in response to Dex $10^{-7} \mathrm{M}$. *: pvalue $<0.05$ between treated and untreated cells. ${ }^{*}: 10.3 \% ;{ }^{\bullet}: 18.4 \%{ }^{+}$: $6.3 \%$; ${ }^{\text {s }}$. $8.2 \%$.

on RB hyperphosphorylation there was no observable effect of dexamethasone on $\mathrm{p} 21^{\mathrm{Cip} 1}, \mathrm{p} 27^{\mathrm{Kip} 1}$ or cyclin D1 expression (fig. 4). These results suggest that in the current system dexamethasone did not stimulate cell cycle progression through G1 by downregulating $\mathrm{p} 21^{\mathrm{Cip} 1}$ or $\mathrm{p} 27^{\mathrm{Kip} 1}$ or by increasing cyclin D1 expression.

A recent report [6] suggested that the loss of the C/EBP $\alpha$ in bronchial smooth muscle from individuals with asthma prevented glucocorticoids from inhibiting proliferation; overexpression of $\mathrm{C} / \mathrm{EBP} \alpha$ restored glucocorticoid's ability to prevent proliferation. This loss of $\mathrm{C} / \mathrm{EBP} \alpha$ appeared to be limited to bronchial smooth muscle as normal amounts were detected in peripheral lymphocytes from affected individuals. To determine whether the loss of $\mathrm{C} / \mathrm{EBP} \alpha$ explained the difference in proliferation between asthmatic and normal fibroblasts, both at baseline and in response to dexamethasone, protein expression in whole cell lysates was examined. The current authors were unable to detect the expression of the 42 $\mathrm{kDa}$ isoform of $\mathrm{C} / \mathrm{EBP} \alpha$, but only the $30 \mathrm{kDa}$ isoform was found to be present. No significant difference in the expression of this $30 \mathrm{kDa}$ isoform between cell types was identified nor was there any significant effect of dexamethasone on protein expression (fig. 4). 
a)

RB-P

RB

$\beta$-actin

c)

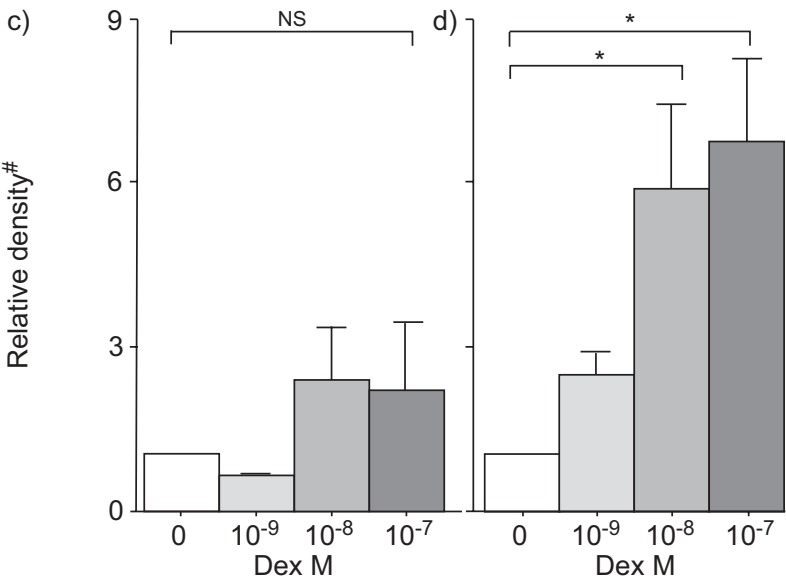

b)

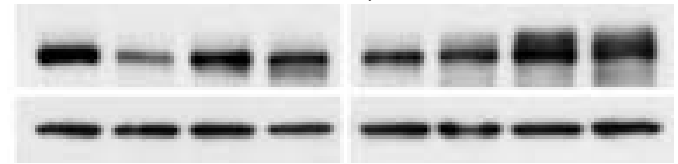

controversies over how to best define and quantify it. Hyperplasia and hypertrophy of airway smooth muscle, thickening of the basement membrane and production of collagen by fibroblasts have all been identified as markers of airway remodelling in asthma. Predictably steroids have different effects on each process depending on the dose and type of steroid, the model system employed and the measured end-points [21-25].

The current study focused on the effect of steroids upon airway fibroblast proliferation and, therefore, is best compared with studies that address this aspect of airway remodelling. WARSHAMAMA et al. [26] demonstrated that dexamethasone increased airway fibroblast proliferation in a human (nonasthmatic) airway fibroblast cell line and also in rat airway fibroblasts; the effect was ameliorated when platelet-derived growth factor isoform AA was blocked. An early study in Swiss 3T3 cells revealed that hydrocortisone increased DNA synthesis, but only in the presence of fibroblast growth factor [8]. However, LEE and Bols [9] demonstrated that cortisol had no effect on proliferation of rainbow trout fibroblasts [9].

In cells isolated directly from human subjects, DuBE et al. [27] demonstrated that proliferation of airway fibroblasts, isolated from subjects with mild-to-moderate asthma, increased $73 \%$ above the negative control after exposure to dexamethasone. These data are consistent with the current authors' previous findings, where a 91\% increase in DNA synthesis above untreated fibroblasts isolated from subjects with mild asthma was demonstrated [7]. However, in a different model system by SILVESTRI et al. [10], fluticasone at concentrations ranging from $0.1-100 \mathrm{nM}$ was found to decrease proliferation and eotaxin expression from fibroblasts cultured from nasal polyps. In addition to the differences in the model system, fluticasone is also 10-100 times more potent than dexamethasone, which may explain the disparate results between these studies [28].

In the current study the authors used a dose of dexamethasone that is within the clinically relevant range and demonstrated that this steroid increased the G1-S phase transition of airway fibroblasts harvested from asthmatic patients. The current authors also demonstrated that even untreated fibroblasts cultured from asthmatic patients had a two-fold increase in the number of cells in S phase at baseline. This suggests important differences exist between asthmatic and normal fibroblasts, in terms of cell cycle regulation, and these differences may contribute to airway remodelling in asthma.

In response to recent reports demonstrating a loss of the transcription factor $\mathrm{C} / \mathrm{EBP} \alpha$ in bronchial smooth muscle cells from asthmatic patients, total cell lysates from both normal and asthmatic fibroblasts were examined. In contrast to the findings of RоTH et al. [6] the current authors were unable to detect the $42 \mathrm{kDa}$ isoform of $\mathrm{C} / \mathrm{EBP} \alpha$ in protein from either type of fibroblasts. However, equal amounts of the $30 \mathrm{kDa}$ isoform of this protein in fibroblasts from both groups were detected. Production of different $\mathrm{C} / \mathrm{EBP} \alpha$ isoforms occurs through the use of alternative initiation codons and represents an important form of translational control under different conditions and in different cell types [29]. The $30 \mathrm{kDa}$ isoform is reported to have a lower transactivation potential than the 42 
a)
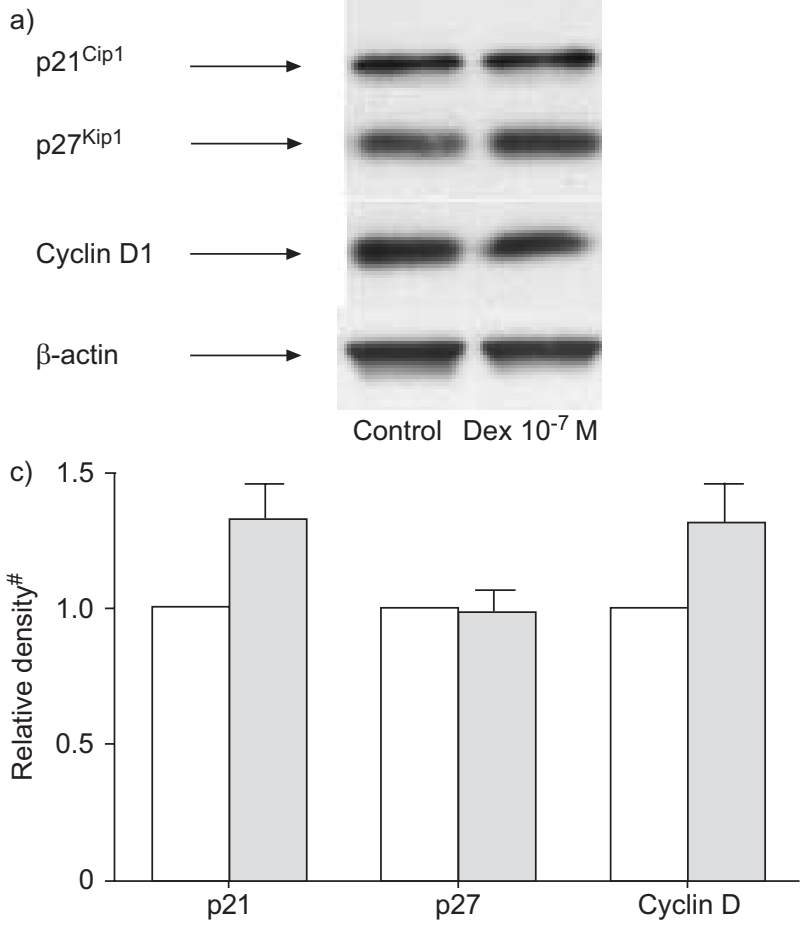

b)

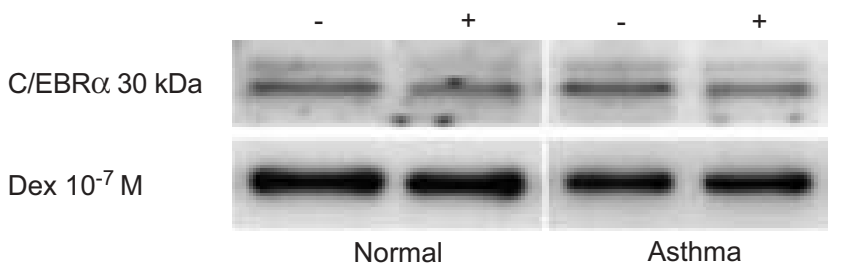

d)

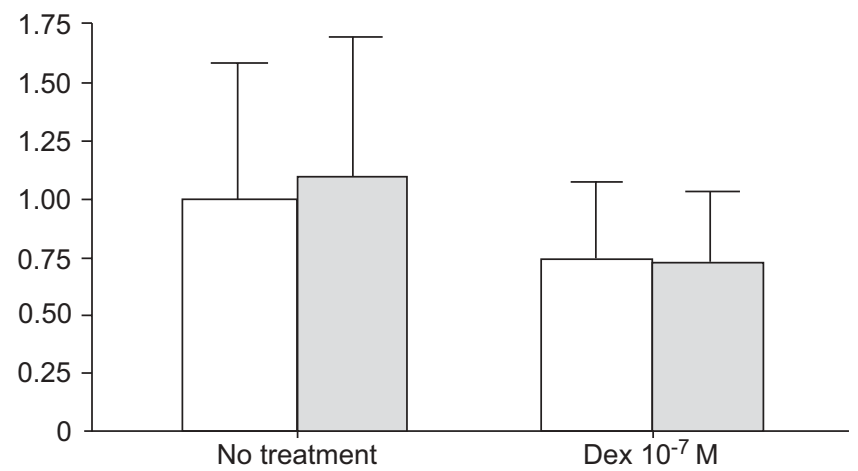

FIGURE 4. a) and b) represent Western blots from a) the asthma group and b) the normal and asthma groups. c) The relative density from seven separate Western blots from the control group with Dex $10^{-7} \mathrm{M}(\square)$ and without $(\square)$. The differences between Dex treated and untreated asthmatic fibroblasts did not reach statistical significance. d) The relative density from six separate Western blots looking at the expression of the CCAAT enhancer binding protein $\alpha(\mathrm{C} / \mathrm{EBP} \alpha)$ in fibroblasts from normal subjects ( $\square$ ) and those with asthma ( $\square$ ). No protein expression for the $42 \mathrm{kDa}$ isoform of C/EBP $\alpha$ was detected so only the data for the $30 \mathrm{kDa}$ protein is presented. The differences between the untreated and Dex treated cells was not signficant. ${ }^{\#}$ : normalised to control.

$\mathrm{kDa}$ isoform, due to the absence of two activating domains; in addition it lacks antimitotic activity in some cells [30, 31]. Whether this difference in isoform expression is due to distinct regulatory functions of $\mathrm{C} / \mathrm{EBP} \alpha$ between airway fibroblasts and bronchial smooth muscle or is due to differences in experimental conditions is not clear.

The effect of dexamethasone on cell cycle proteins, particularly RB, has been examined by others. Dexamethasone inhibited the hyperphosphorylation of RB and induced G1 arrest in human vascular smooth muscle cells exposed to 10\% FBS [32]. In cultured human airway smooth muscle cells, FERNANDES et al. [33] demonstrated that dexamethasone could block thrombin-mediated increases in DNA synthesis and did so by blocking the hyperphosphorylation of RB. In contrast, the current authors' experiments demonstrate that dexamethasone (at similar doses) led to the hyperphosphorylation of RB, with an increase in cells progressing through the cell cycle. A few important differences in study design explain these opposing results. First, the current study investigated the effect of dexamethasone on unstimulated $(0.5 \%$ serum $)$ rather than stimulated (10\% FBS or thrombin) cells. This is because the current authors were interested in looking at the potential proliferative effect of dexamethasone on unstimulated fibroblasts, rather than confirming its previously documented antiproliferative effect on cells exposed to growth factors [6, $32,33]$. Secondly the current study investigated earlier passage cells (never using greater than third passage) and finally, the current authors compared cells obtained from patients with asthma to those from normal patients.

An important limitation of this study is that it was not determined whether dexamethasone caused changes in cell number. As a result there are two different conclusions that can be drawn from the data presented. First, that dexamethasone preferentially induced fibroblasts from asthmatics to enter the cell cycle and divide. Secondly, that dexamethasone preferentially induced a prolongation of $S$ phase in fibroblasts from asthmatics causing cells to accumulate there. Further studies will be needed to distinguish between these two possibilities. Another potential limitation is that the current authors studied the effect of dexamethasone on nonsynchronised fibroblasts at a single time point $(72 \mathrm{~h})$. This precluded determining the time course during which fibroblasts arrested (synchronised) in G0/G1 would progress from G1 to S phase in response to dexamethasone. Despite these limitations, the marked differences in RB phosphorylation and cell cycle profile between fibroblasts from normal and asthmatic subjects, following exposure to dexamethasone, suggests that the effect of steroids on cells in the airway is not completely predictable and may induce cell cycle progression in fibroblasts from individuals with asthma.

In conclusion, the current data suggests that dexamethasone selectively induces the transition from G1 to $S$ phase of the cell cycle in airway fibroblasts cultured from asthmatics and does so through the hyperphosphorylation of retinoblastoma. 
Whether dexamethasone's ability to enhance this transition leads to clinically relevant (and deleterious) effects on airway remodelling, such as enhanced matrix expression by airway fibroblasts, is intriguing but will require further investigation.

\section{REFERENCES}

1 Busse W, Elias J, Sheppard D, Banks-Schlegel S. Airway remodeling and repair. Am J Respir Crit Care Med 1999; 160: 1035-1042.

2 Brewster CE, Howarth PH, Djukanovic R, Wilson J, Holgate ST, Roche WR. Myofibroblasts and subepithelial fibrosis in bronchial asthma. Am J Respir Cell Mol Biol 1990; 3: $507-511$.

3 Elias JA, Freundlich B, Kern JA, Rosenbloom J. Cytokine networks in the regulation of inflammation and fibrosis in the lung. Chest 1990; 97: 1439-1445.

4 Gauldie J, Jordana M, Cox G, Ohtoshi T, Dolovich J, Denburg J. Fibroblasts and other structural cells in airway inflammation. Am Rev Respir Dis 1992; 145: S14-S17.

5 Standards for the diagnosis and care of patients with chronic obstructive pulmonary diseaseasthma, Am Rev Respir Dis 1987; 136: 225-244.

6 Roth M, Johnson PR, Borger $\mathrm{P}$, et al. Dysfunctional interaction of $\mathrm{C} / \mathrm{EBPalpha}$ and the glucocorticoid receptor in asthmatic bronchial smooth-muscle cells. N Engl J Med 2004; 351: 560-574.

7 Kraft M, Lewis C, Pham D, Chu HW. IL-4, IL-13, and dexamethasone augment fibroblast proliferation in asthma. J Allergy Clin Immunol 2001; 107: 602-606.

8 Richmond KM, Kubler AM, Martin F, Jimenez de Asua L. The stimulation of the initiation of DNA synthesis by fibroblast growth factor in Swiss 3T3 cells: interactions with hormones during the pre-replicative phase. J Cell Physiol 1980; 103: 77-85.

9 Lee LE, Bols NC. Action of cortisol on the proliferation of rainbow trout fibroblasts. Cell Tissue Kinet 1989; 22: 291-301.

10 Silvestri M, Sabatini F, Scarso L, Cordone A, Dasic G, Rossi GA. Fluticasone propionate downregulates nasal fibroblast functions involved in airway inflammation and remodeling. Int Arch Allergy Immunol 2002; 128: 51-58.

11 National Asthma Education Prevention Program, Guidelines for the diagnosis and management of asthma. Expert Panel Report 1997; 2: 1-146.

12 Kraft M, Bettinger CM, Wenzel SE, Irvin CG, Ackerman SJ, Martin RJ. Methacholine challenge does not affect bronchoalveolar fluid cell number and many indices of cell function in asthma. Eur Respir J 1995; 8: 1966-1971.

13 Krishan A. Rapid flow cytofluorometric analysis of mammalian cell cycle by propidium iodide staining. J Cell Biol 1975; 66: 188-193.

14 Fouty BW, Rodman DM. Mevastatin can cause G1 arrest and induce apoptosis in pulmonary artery smooth muscle cells through a p27Kip1-independent pathway. Circ Res 2003; 92: 501-509.

15 Vidal A, Koff A. Cell-cycle inhibitors: three families united by a common cause. Gene 2000; 247: 1-15.

16 Sherr CJ, Roberts JM. CDK inhibitors: positive and negative regulators of G1-phase progression. Genes Dev 1999; 13: 1501-1512.
17 Gallo R, Padurean A, Jayaraman T, et al. Inhibition of intimal thickening after balloon angioplasty in porcine coronary arteries by targeting regulators of the cell cycle. Circulation 1999; 99: 2164-2170.

18 Laufs U, Marra D, Node K, Liao JK. 3-Hydroxy-3methylglutaryl-CoA reductase inhibitors attenuate vascular smooth muscle proliferation by preventing rho GTPaseinduced down-regulation of p27(Kip1). J Biol Chem 1999; 274: 21926-21931.

19 Lambert RK, Wiggs BR, Kuwano K, Hogg JC, Pare PD. Functional significance of increased airway smooth muscle in asthma and COPD. J Appl Physiol 1993; 74: 2771-2781.

20 Wiggs BR, Bosken C, Pare PD, James A, Hogg JC. A model of airway narrowing in asthma and in chronic obstructive pulmonary disease. Am Rev Respir Dis 1992; 145: 1251-1258.

21 Hoshino M, Takahashi M, Takai Y, Sim J. Inhaled corticosteroids decrease subepithelial collagen deposition by modulation of the balance between matrix metalloproteinase- 9 and tissue inhibitor of metalloproteinase-1 expression in asthma. J Allergy Clin Immunol 1999; 104: 356-363.

22 Lundgren R, Soderberg M, Horstedt P, Stenling R. Morphological studies of bronchial mucosal biopsies from asthmatics before and after ten years of treatment with inhaled steroids. Eur Respir J 1988; 1: 883-889.

23 Trigg CJ, Manolitsas ND, Wang J, et al. Placebo-controlled immunopathologic study of four months of inhaled corticosteroids in asthma. Am J Respir Crit Care Med 1994; 150: 17-22.

24 Sont JK, Willems LN, Bel EH, van Krieken JH, Vandenbroucke JP, Sterk PJ. Clinical control and histopathologic outcome of asthma when using airway hyperresponsiveness as an additional guide to long-term treatment. The AMPUL Study Group. Am J Respir Crit Care Med 1999; 159: 1043-1051.

25 Jeffery PK, Godfrey RW, Adelroth E, Nelson F, Rogers A, Johansson SA. Effects of treatment on airway inflammation and thickening of basement membrane reticular collagen in asthma. A quantitative light and electron microscopic study. Am Rev Respir Dis 1992; 145: 890-899.

26 Warshamana GS, Martinez S, Lasky JA, Corti M, Brody AR. Dexamethasone activates expression of the PDGF-alpha receptor and induces lung fibroblast proliferation. Am J Physiol 1998; 274: L499-L507.

27 Dube J, Chakir J, Laviolette $\mathrm{M}$, et al. In vitro procollagen synthesis and proliferative phenotype of bronchial fibroblasts from normal and asthmatic subjects. Lab Invest 1998; 78: 297-307.

28 Esmailpour N, Hogger P, Rabe KF, Heitmann U, Nakashima M, Rohdewald P. Distribution of inhaled fluticasone propionate between human lung tissue and serum in vivo. Eur Respir J 1997; 10: 1496-1499.

29 Ramji DP, Foka P. CCAAT/enhancer-binding proteins: structure, function and regulation. Biochem J 2002; 365: 561-575.

30 Ossipow V, Descombes P, Schibler U. CCAAT/enhancerbinding protein mRNA is translated into multiple proteins with different transcription activation potentials. Proc Natl Acad Sci USA 1993; 90: 8219-8223.

31 Lin FT, MacDougald OA, Diehl AM, Lane MD. A 30-kDa alternative translation product of the CCAAT/enhancer binding protein alpha message: transcriptional activator 
lacking antimitotic activity. Proc Natl Acad Sci USA 1993; 90: 9606-9610.

32 Reil TD, Kashyap VS, Sarkar R, Freishlag J, Gelabert HA. Dexamethasone inhibits the phosphorylation of retinoblastoma protein in the suppression of human vascular smooth muscle cell proliferation. J Surg Res 2000; 92: 108-113.
33 Fernandes D, Guida E, Koutsoubos V. Glucocorticoids inhibit proliferation, cyclin D1 expression, and retinoblastoma protein phosphorylation, but not activity of the extracellular-regulated kinases in human cultured airway smooth muscle. Am J Respir Cell Mol Biol 1999; 21: 77-88. 